\title{
Effects of an offshore oil platform on the distribution and abundance of commercially important crab species
}

\author{
Henry M. Page ${ }^{1, *}$, Jenifer E. Dugan ${ }^{1}$, Daniel S. Dugan ${ }^{2}$, John B. Richards ${ }^{1}$, \\ David M. Hubbard ${ }^{1}$
}

\author{
${ }^{1}$ Marine Science Institute, University of California, Santa Barbara, California 93106, USA \\ ${ }^{2}$ Biological Sciences Department, California Polytechnic State University, San Luis Obispo, California 93407, USA
}

\begin{abstract}
The distribution, abundance, and population characteristics of large, highly mobile crab species (Cancer antennarius, C. anthonyi, C. productus, Loxorhynchus grandis) differed in relation to an offshore oil platform in the Santa Barbara Channel, California, USA. Only $C$. antennarius individuals recruited onto the platform, primarily into the attached community of Mytilus galloprovincialis and $M$. californianus at depths of $<12$ to $15 \mathrm{~m}$. The higher CPUE (catch per unit effort) of $C$. antennarius beneath the platform, compared with nearby soft bottom stations, suggested that this species remained primarily in the vicinity of the platform. Although $C$. anthonyi did not recruit at the platform, adult female $C$. anthonyi were attracted to the platform from surrounding habitat. The higher CPUE of female $C$. anthonyi beneath the platform, compared with soft bottom stations, suggested that habitat selection is related to reproduction in this species. C. productus and Loxorhynchus grandis were present in low numbers at all benthic stations. The distribution and abundance of these crab species fit into 3 of 4 hypothesized scenarios that described different combinations of recruitment, distribution and abundance of mobile species around oil platforms: (1) 'recruitment/emigration', a platform provides recruitment habitat and individuals that recruit to the platform emigrate at some point to the surrounding environment, (2) 'recruitment/resident', a platform provides recruitment habitat, but individuals remain in the vicinity of the structure (C. antennarius), (3) 'attraction', individuals that recruited elsewhere are attracted to and aggregate at a platform (C. anthonyi), and (4) 'visitor', individuals that recruited elsewhere occur temporarily at the platform without aggregation ( $C$. productus, L. grandis). Our results, in the context of these scenarios, illustrate the need to consider the responses of individual species to artificial structures.
\end{abstract}

KEY WORDS: Oil platform - Crabs · Cancridae - Majidae $\cdot$ Mussels $\cdot$ Mytilus

\section{INTRODUCTION}

Artificial structures can dramatically alter the species composition, distribution, and abundance of local invertebrate and fish fauna. Typically located on soft mud or sand bottom, artificial structures provide hard attachment sites for sessile invertebrates and may attract and aggregate mobile invertebrates and fishes (e.g. Wolfson et al. 1979, Davis et al. 1982, Bohnsack 1989, Love et al. 1994, Herrnkind et al. 1997). Observations of aggregations of fishes around artificial reefs

\footnotetext{
•E-mail:page@lifesci.lscf.ucsb.edu
}

and oil platforms, in particular, have fueled the 'production versus attraction' controversy. Do these structures enhance the recruitment, growth, and/or survival of individuals or do they simply attract and concentrate individuals from surrounding habitats (e.g. Reggio 1989, Bohnsack et al. 1997, Carr \& Hixon 1997, Herrnkind et al. 1997, Lindberg 1997)?

Offshore oil and gas platforms are among the largest artificial structures in the marine environment. It has been proposed in the 'rigs to reef' concept that obsolete oil and gas structures can serve as artificial reefs (Reggio 1987, 1989). Obsolete structures are cropped or toppled in place or towed and submerged in a dif- 


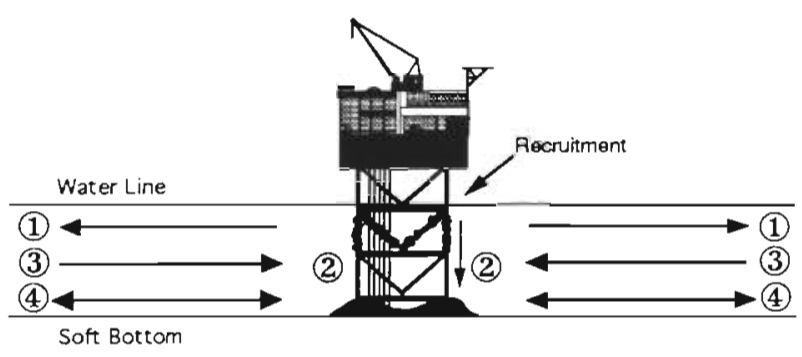

Fig. 1. Diagram illustrating 4 possible distribution and abundance scenarios for large, mobile crab species relative to an offshore oil platform. (1) 'Recruitment/emigration'-recruitment to platform; emigration from platform, (2) 'recruitment/resident'-recruitment to platformi resident population, (3) 'attraction'-attraction of individuals that recruited elsewhere, (4) 'visitor'-individuals that recruited elsewhere occur temporarily at the platform without aggregation

ferent location, providing hard substrata in a typically soft bottom environment. However, the 'rigs to reef' concept is controversial in some regions. While recreational fishermen may support the concept because of the apparent aggregation of fishes around these structures, commercial trawl fishermen often prefer platform removal due to the potential of fouling gear and loss of access to fishable areas (Picken \& McIntyre 1989, MMS/State Lands Commisson 1994). Part of the controversy exists because of a lack of information on the mechanisms by which active oil platforms, de facto artificial. reefs, affect the distribution and abundance of recreational and commercially important species.

Three species of commercially important cancrid crabs (Cancer antennarius, $C$. anthonyi, $C$. productus), and the majid crab Loxorhynchus grandis are fished in the vicinity of platforms offshore of southern California, USA. Platforms may affect the distribution and abundance of these large, mobile crustaceans through the alteration of physical habitat and local infaunal and epifaunal benthic communities. The platform structure (support members, conductor pipes) and attached invertebrate community may provide potential habitat and food for crabs. The attached invertebrate community is often many centimeters thick on platforms along the central and south coast of California; many of the species (e.g. Mytilus californianus, M. galloprovincialis, Pollicipes polymerus) are also components of rocky and pier piling intertidal and subtidal communities (Bascom et al. 1976, Stimpson 1977, Wolfson et al. 1979, Page 1986, Page \& Hubbard 1987).

Food availability and habitat heterogeneity beneath a platform may also attract crabs. Clumps of mussel community, dislodged from the platform structure, fall to the bottom as 'faunal litterfall'. Over time, faunal litterfall creates a 'shell mound' extending in height several meters off the original bottom (reviewed in MBC
1987). The shell mound provides hard attachment sites, microhabitats, and food for an assemblage of invertebrate species typically not present on soft bottom. For example, Wolfson et al. (1979) reported unusually high densities of echinoderms (e.g. Pisasterspp., Patiria miniata) beneath Platform Eva, $3 \mathrm{~km}$ of fshore of Huntington Beach, southern California $\left(33^{\circ} 40^{\prime} \mathrm{N}, 118^{\circ} 93^{\prime} \mathrm{W}\right)$, feeding on mussels dislodged from the structure.

Based on our preliminary observations and on ideas developed for the potential effects of artificial reefs on fish populations (reviews by Bohnsack \& Sutherland 1985, Bohnsack 1989, Pickering \& Whitmarsh 1997), we hypothesized that the distribution and abundance of highly mobile, commercially important crab species may fit into 1 of 4 scenarios (Fig. 1). In the 'recruitment/ emigration' scenario, a platform provides recruitment habitat and individuals that recruit to the platform emigrate at some point to the surrounding environment, contributing to the regional production of a species There may be no way of knowing whether the recruitment of these individuals would have occurred elsewhere, but this scenario is closest to the production of new biomass hypothesis reviewed in Bohnsack (1989). In the 'recruitment/resident' scenario, the platform also provides recruitment habitat, but individuals remain in the vicinity of the structure, forming a resident population. In the 'attraction' scenario, individuals that recruited elsewhere are attracted to and aggregate at the platform. The attraction scenario could also lead to increased regional production through, for example, the increased growth rate and/or survival of individuals while at the structure. This pattern may occur seasonally or throughout the year. Finally, in the 'visitor' scenario, individuals that recruited elsewhere occur temporarily at the platform without aggregation; these individuals may also be present seasonally or throughout the year

The objectives of our study, emphasizing commercially important crab species, were to: (1) test whether crabs occurred in higher densities beneath a platform compared to adjacent soft bottom, (2) characterize spatial and temporal patterns of crab recruitment to a platform, including the importance of the platform invertebrate community as a potential habitat and source of food for crabs, and (3) evaluate our data in the context of the 4 hypothesized scenarios described above which reflect different combinations of recruitment, and of distribution and abundance of mobile species around oil platforms

\section{MATERIALS AND METHODS}

Study site. This study was conducted $-3 \mathrm{~km}$ offshore of Goleta, California $\left(34^{\circ} 25^{\prime} \mathrm{N}, 119^{\circ} 52^{\prime} \mathrm{W}\right)$, in the 
Santa Barbara Channel at and in the vicinity of the oil and natural gas platform 'Holly' (Mobil, Venoco: Fig. 2). The platform is $19 \times 36 \mathrm{~m}$ at the water line. Bottom depth at the platform is $-66 \mathrm{~m}$.

Support members and conductor pipes are covered intertidally and subtidally by a community of sessile and semi-mobile invertebrates. On Platform Holly, mussels contributed most to community biomass to a depth of $\sim 12 \mathrm{~m}$ while barnacles (e.g. Megabalanus californicus, Balanus aquila), encrusting bivalves (e.g. Chama arcana, Crassadoma gigantea), and anemones (Metridium senile), were more abundant deeper. Mytilus galloprovincialis comprised nearly $100 \%$ of the mussels at depths shallower than $\sim 6 \mathrm{~m}$ while large clumps of Mytilus californianus were present between $9 \mathrm{~m}$ and $12 \mathrm{~m}$. Thirty conductor pipes arranged in 3 rows of 10 pipes $1 \mathrm{~m}$ apart provided replicate surfaces for measurements of invertebrate community thickness and the sampling of crabs on the structure.

Invertebrate community and faunal litterfall. To characterize the invertebrate community as potential crab habitat, we determined community thickness on randomly selected conductor pipes $(1.64 \mathrm{~m}$ diameter without attached invertebrates, $\mathrm{n}=4$ ) monthly at 4 depths $(6,12,18$, and $24 \mathrm{~m})$ from August 1995 to August 1996. Measurements of circumference were converted to estimates of radius $(r=C / 2 \pi)$. Invertebrate community thickness was calculated as the difference between the radius of a conductor pipe with and without the attached invertebrates.

To estimate rates of faunal litterfall from conductor pipes to the benthos, traps $(n=3)$ were suspended between pairs of pipes at a depth of $18 \mathrm{~m}$ and retrieved monthly from October 1995 to September 1996. The traps consisted of $38 \mathrm{~cm}$ internal diameter (area = $0.113 \mathrm{~m}^{2}$ ) plastic circular hoops with attached $1.4 \mathrm{~mm}$ mesh bags. Since faunal litterfall consisted primarily of mussels and associated epifauna by weight (e.g. attached barnacles, anemones), the contents of the bags were sorted by mussel species (Mytilus californianus or M. galloprovincialis). Wet biomass of each mussel species and associated epifauna was determined using a spring scale after draining the sample of excess water. Displacement volume was measured for some samples by water displacement in a calibrated bucket.

Video recordings taken from a manned submersible (Delta) on October 29, 1996 provided qualitative information on bottom topography. The video recordings were taken along the north, south, east, and west outer margins of the structure.

Effect of platform structure on benthic distribution and abundance of crabs. Baited traps (Fathom Plus ${ }^{T M}$ ) were used to evaluate the effect of location (immediately beneath the platform vs soft bottom) and time of

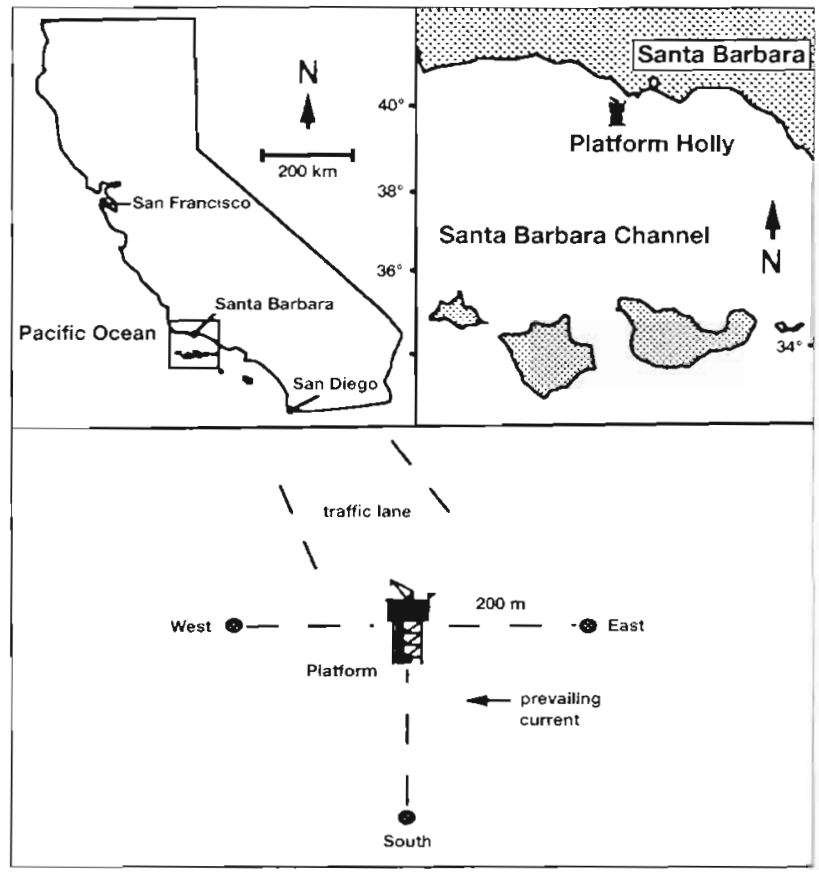

Fig. 2. Map showing the location of the oil and natural gas platform study site in the Santa Barbara Channel (Platform. Holly) and the arrangement of sampling stations around the platform

year on the abundance of adult crabs. The traps were baited with a total of $1.4 \mathrm{~kg}$ of coarsely chopped mackerel Scomber japonicus enclosed in 2 plastic mesh containers (mesh size $=\sim 5 \mathrm{~mm}$ ). Traps were deployed monthly beneath the platform from July 1995 to August 1997 ( $n=4$ traps) and retrieved after a 22 to $24 \mathrm{~h}$ immersion time. Because of prevailing east to west currents, traps were deployed along the west side of the platform to prevent entanglement in the structure. Traps were deployed on soft bottom every 2 mo $\sim 200$ m east, south, and west of the platform from October 1995 to May 1997 ( $n=3$ traps at each location: Fig. 2). Depth of the bottom at these stations ranged from $\sim 60$ to $64 \mathrm{~m}$. The crewboat transportation corridor along the north side of the platform precluded deployment of traps at this location.

Crabs in the traps were identified to species and sex, measured, and the presence of eggs recorded. For cancrid crabs, carapace width (CW) was measured as the distance to the nearest $1 \mathrm{~mm}$ between the outermost anterolateral teeth. For majid crabs, carapace length (CL) was measured to the nearest $1 \mathrm{~mm}$ from the notch in the rostrum to the posterior end of the carapace. Trapping results are expressed as catch per unit effort (CPUE).

Video recordings taken from the submersible also provided semi-quantitative information on the abun- 
dance of adult cancrid and majid crabs on the bottom. Crabs in the video within an $\sim 2$ mide swath along each of the 4 sides of the structure were counted and identified to genus or species where possible.

To assess potential movement of crabs between the platform and surrounding benthic habitats, all cancrid crabs $>95 \mathrm{~mm} \mathrm{CW}$ were tagged $\sim 1 \mathrm{~cm}$ from the right margin of the epimeral suture with individually labeled yellow T-bar anchor tags (Floy FD-94) and released at the site of capture.

The platiorm structure as habitat. Recruitment of crabs: To measure spatial and temporal variation in the recruitment of crabs to the platform, we deployed recruitment cages $(12 \times 30 \mathrm{~cm}$ cylinders of $12 \mathrm{~mm}$ mesh vexar) filled with $5 \mathrm{~kg}$ of mussel community typically found at a depth of $12 \mathrm{~m}$ (Mytilus californianus, M. galloprovincialis and associated organisms) from March 1996 to September 1997. Prior to deployment, the mussel community was carefully searched and all crabs removed. The recruitment cages were attached to conductor pipes at depths of 12, 18, and $24 \mathrm{~m}$, and deployed on the bottom $(66 \mathrm{~m})$ ( $\mathrm{n}=3$ to 4 at each depth). Cages were retrieved bimonthly and the mussel cornmunity removed and searched. Crabs within the cages were identified to species and sex (where possible) and measured.

Distribution and abundance of crabs: To further examine temporal variation in the recruitment and size structure of crabs on the platform, crabs were sampled on at least 4 conductor pipes at 3 depths $(12,18$, and $24 \mathrm{~m}$ ) using SCUBA every other month from October 1995 to November 1996 and monthly from December 1996 to July 1997. Conductor pipe sites were selected randomly at each depth. On the conductor pipes, a $0.82 \times 2.46 \mathrm{~m}\left(2 \mathrm{~m}^{2}\right)$ area was searched by 2 divers and crabs removed by hand

Crabs concealed within the mussel community at a depth of $12 \mathrm{~m}$ were sampled by removing 5 to $10 \mathrm{~kg}$ of mussels at each station into $1.4 \mathrm{~mm}$ mesh bags. The wet weight of Mytilus californianus and $M$. galloprovincialis and associated fauna was determined in the laboratory as above. Crabs in the samples were identified to species and sex (where possible) and measured. Crab density was standardized to $5 \mathrm{~kg}$ wet wt of mussel community, or to area $\left(\mathrm{m}^{2}\right)$ using data on the volume of the mussel sample $\left(\mathrm{m}^{3}\right)$ divided by the thickness of the attached community (m).

Crabs were also sampled on horizontal and diagonal support members between depths of $9 \mathrm{~m}$ and $18 \mathrm{~m}$ in February 1995, December and May 1996 and August 1997. Support members were carefully searched by divers and crabs removed by hand.

To compare the relative abundance of larger crabs (>80 $\mathrm{mm} \mathrm{CW}$ ) on the platform with the bottom, 3 Fathom Plus traps were deployed on horizontal mem- bers among the conductor pipes at a depth of $9 \mathrm{~m}$ on 7 dates from November 1995 to June 1997.

Statistical analyses. All statistical analyses were done using Systat 5.2 (Wilkinson et al. 1992). The effects of independent variables (depth, location, and/ or time) on the dependent variables (i.e. thickness of the invertebrate community, faunal litterfall rates, and crab density) were evaluated using repeated measures analysis of variance (ANOVA). This statistic was appropropriate since our study involved repeated sampling at 1 platform. Post hoc univariate $F$-tests were used to identify significant differences in mean values among locations, depths, and times. Tests for differences in the relative abundance of crab species between depths of 9 and $66 \mathrm{~m}$ were made using a paired $t$-test by sampling date. Comparisons of individual mean size between locations were made for each crab species with unpaired $t$-tests. Data were log transformed $\left[x^{\prime}=\log _{10}(x+1)\right]$ prior to analysis to correct for heteroscedasticity ( $\operatorname{Zar} 1984$ ). A chi-square test was used to test for significant deviations from a predicted proportion of 0.50 male individuals for each species.

\section{RESULTS}

\section{Platform invertebrate community and faunal litterfall to the benthos}

The invertebrate community on platform conductor pipes varied in thickness with depth and time (depth $x$ time, $p<0.05, F=1.85$, df $=24,56,2$-way ANOVA). Thickness was greatest over time at a depth of $12 \mathrm{~m}$ (except on July 27, 1996, $\mathrm{p}<0.05$, post hoc F-tests) and least at depths of 18 and $24 \mathrm{~m}$ (Fig. 3a). The increase in mean thickness over time at $6 \mathrm{~m}$ from $6.3 \pm 1.2$ in August 1995 to $15.3 \pm 0.4 \mathrm{~cm}$ in August 1996 reflects the recolonization of conductor pipes by mussels (primarily Mytilus galloprovincialis) following a maintenance cleaning at this depth during summer 1995.

Rates of faunal litterfall to the benthos varied significantly over time $(p<0.05, F=2.32$, df $=9,27,1$-way ANOVA), ranging from $0.08 \pm 0.03$ to $2.60 \pm 0.81 \mathrm{~kg}$ wet wt trap ${ }^{-1} w^{-1}(\bar{x} \pm 1 \mathrm{SE}$ : Fig. 3b). Rates of faunal litterfall were significantly higher October to March and August to September compared with April to June $(\mathrm{p}<0.05, F=$ 18.83, df $=1,3$, post hoc F-test). Overall, dislodged clumps of Mytilus galloprovincialis formed $92.8 \pm 3.3 \%$ ( $n=28$ ) of this material. The wet weight and displacement volume of mussel clumps were highly correlated and described by the following relationship: $v=0.74$ $( \pm 0.02, \pm 1 \mathrm{SE}) w-0.04( \pm 0.12), \mathrm{r}=0.99, \mathrm{p}<0.001, \mathrm{df}=28$, where $v=$ volume $\left(\times 10^{3} \mathrm{~cm}^{3}\right)$ and $w=$ wet weight $(\mathrm{kg})$.

Video recordings from the submersible showed that the topography of mud soft bottom beneath the plat- 
form is covered by a mound of mussel shells and other debris with an estimated height of 3 to $4 \mathrm{~m}$. The mound was highest towards the west and north side of the platform. Mud substratum was visible on the east side of the platform

\section{Effect of platform structure on benthic distribution and abundance of crabs}

Three species of Cancer (C. antennarius, C. anthonyi, $C$. productus) and the majid crab Loxorhynchus grandis were caught in traps deployed on the bottom There were no significant differences among soft bottom stations in CPUE with location or time $(p>0.1,2$ way ANOVA) and these data were pooled for each species in subsequent analyses ( $n=9$ stations). There was a strong effect of location (platform vs soft bottom) on CPUE for $C$. antennarius and $C$. anthonyi $(p<0.001$, 2-way ANOVA: Table 1). The mean CPUE of $C$. antennarius was significantly higher beneath the platform than at the soft bottom stations on each sampling date ( $p<0.05$, post hoc F-tests: Fig. 4a). The mean CPUE of $C$. anthonyi was also significantly higher at the platform compared with the soft bottom stations ( $p<0.05$, post hoc F-tests: Fig. 4b) except in November 1996 and January 1997 . No effect of location on CPUE was found for C. productus and L. grandis (Table 1, Fig. 4c,d).

Video recordings showed a patchy distribution of crabs on the mussel mound. The density of cancrid crabs ranged from $0.5 \mathrm{crab} 10 \mathrm{~m}^{-2}$ (east, west, and south transects) to 2 crabs $10 \mathrm{~m}^{-2}$ along the north transect. Densities of Loxorhynchus grandis ranged from $0.2 \mathrm{crab} 10 \mathrm{~m}^{-2}$ along the east and south transects to 2 crabs $10 \mathrm{~m}^{-2}$ along the west and north transects.

A strong effect of time on CPUE was found for Cancer anthonyi and Loxorhynchus grandis (Table 1, Fig. 4). For C. anthonyi, mean CPUE values during the winter and spring (January to May, $\geq 3.0$ crabs trap $^{-1}$ ) were significantly higher than during summer and fall (June to November, $\leq 2.0$ crabs trap ${ }^{-1}: \mathrm{p}<0.001, F=$ 24.94, df $=1,9$, post hoc F-test). For L. grandis, mean CPUE values were significantly higher in the fall and early winter months than other times of the year (Octo-
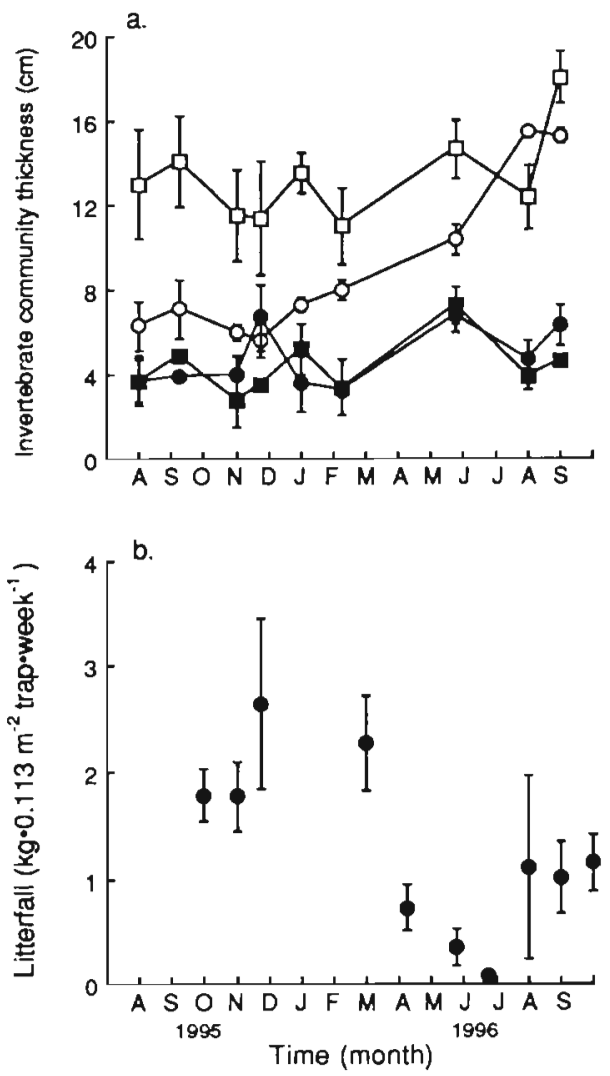

Fig. 3. (a) Thickness of the invertebrate community at depths of $6 \mathrm{~m}(0), 12 \mathrm{~m}(\mathrm{a}), 18 \mathrm{~m}(\bullet)$, and $24 \mathrm{~m}(\mathbf{\square}) . \mathrm{n}=4$ to 6 conductor pipes, and (b) faunal litterfall over time measured at a depth of $18 \mathrm{~m}, \mathrm{n}=3$ faunal litterfall traps, $\bar{x}= \pm 1 \mathrm{SE}$

ber 1995 and November 1996 vs the other 7 mo, p < $0.05, F=5.31, \mathrm{df}=1,9$, post hoc $F$-test).

There was no correlation $(p>0.1)$ between the monthly mean CPUE of Cancer antennarius, $C$. anthonyi, C. productus, or Loxorhynchus grandis beneath the platform and monthly faunal litterfall rates measured at the conductor pipes.

A total of 780 cancrid crabs were tagged in this study (368 Cancer antennarius, 347 C. anthonyi, and $65 \mathrm{C}$. productus). Recapture rates were low for all species at the platform (C. antennarius: $1.4 \%, C$. anthonyi: $0.9 \%$, C. productus: $3.1 \%$ ). No tagged individuals were

Table 1. Results of repeated measures 2-way ANOVA evaluating the effect of location and time (platform vs soft bottom) on the abundance (CPUE) of Cancer spp and of Loxorhynchus grandis. Data $\log _{10}(x+1)$ transformed prior to analysis

\begin{tabular}{|c|c|c|c|c|c|c|c|c|c|}
\hline \multirow[t]{2}{*}{ Species } & \multicolumn{3}{|c|}{ Location } & \multicolumn{3}{|c|}{ Time } & \multicolumn{3}{|c|}{ Location $\times$ Time } \\
\hline & $F$ & $\mathrm{p}$ & $\mathrm{df}$ & $F$ & $\mathrm{p}$ & $\mathrm{df}$ & $F$ & $\mathrm{p}$ & df \\
\hline C. antennarius & 98.33 & $<0.001$ & 1,9 & 1.89 & 0.07 & 8,72 & 3.09 & $<0.01$ & 8,72 \\
\hline C. anthonyi & 27.13 & $<0.001$ & 1,9 & 2.87 & $<0.01$ & 8,72 & 4.54 & $<0.001$ & 8,72 \\
\hline C. productus & 0.76 & $>0.1$ & 1,9 & 1.99 & 0.06 & 8,72 & 1.62 & $>0.1$ & 8,72 \\
\hline L. grandis & 0.12 & $>0.1$ & 1,9 & 3.69 & 0.001 & 8,72 & 0.91 & $>0.1$ & 8,72 \\
\hline
\end{tabular}



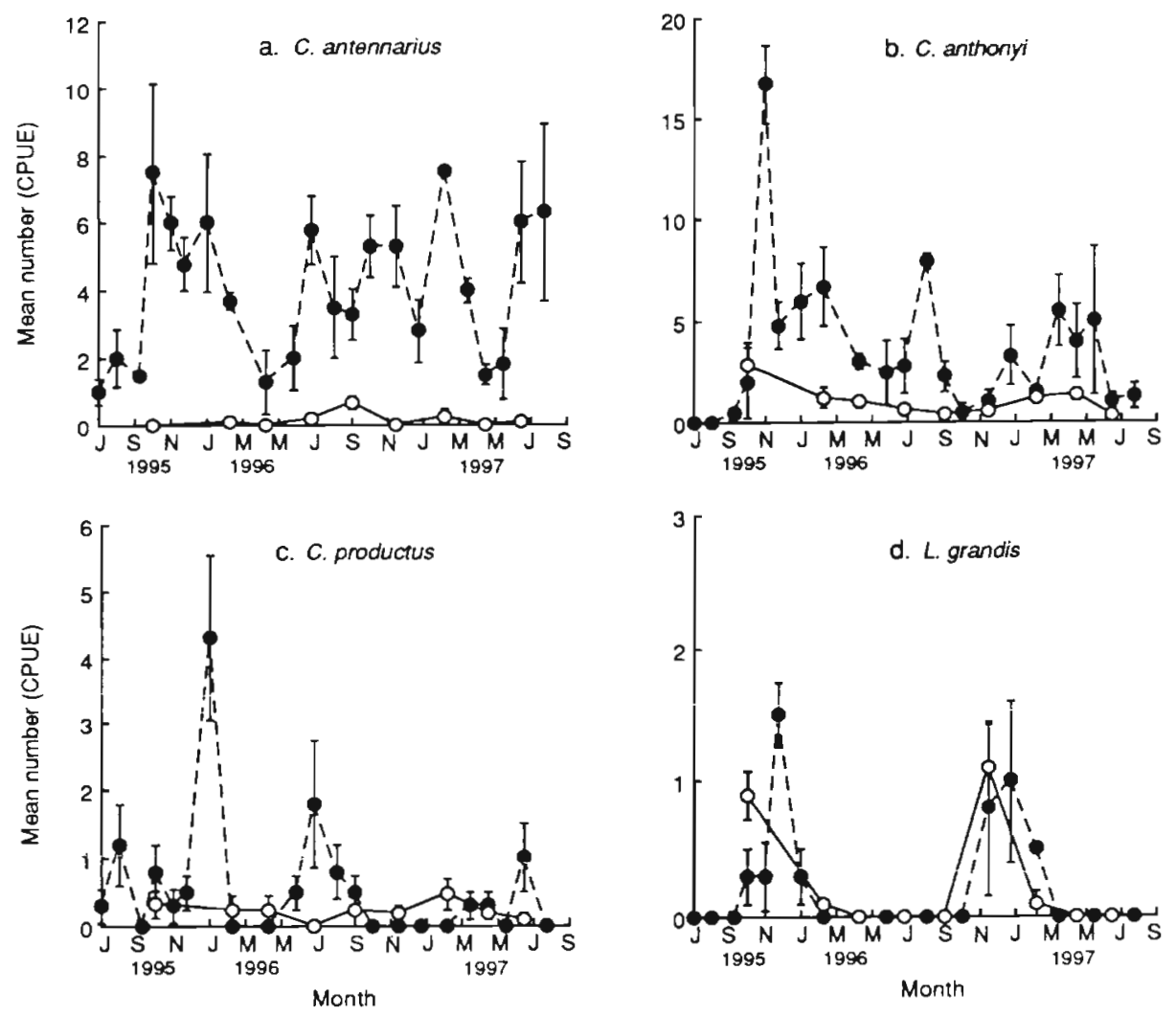

Fig. 4. Spatial and temporal patterns in the abundance (expressed as CPUE) of (a) Cancer antennarius, (b) C. anthonyi, (c) C. productus, and (d) Loxorhynchus grandis beneath Platform Holly and on adjacent soft bottom. Locations: Platform Holly $(\bullet)$, grouped soft bottom stations (o). $n=3$ to 4 traps at Holly, $n=9$ traps at soft bottom stations, $\bar{x} \pm 1$ $S E$. Note differences among figures in scale of $y$-axis

recaptured at the soft bottom stations. However, by November 1997, 10 tagged C. anthonyi were caught in traps set by local fishermen at distances of up to $8 \mathrm{~km}$

Table 2. Population characteristics of Cancer spp. and Loxorhynchus grandis. $x_{m}$ : mean size of male crabs; $x_{f}$ : mean size of female crabs, carapace width for Cancer spp., carapace length for $L$. grandis, mean values, $m m \pm 1 S E$, sample sizes in parentheses, $n_{m} /\left(n_{m}+n_{i}\right)$ : proportion of male crabs in the samples; significance levels for chi-square test against a theoretical proportion of 0.50 male crabs. $\cdot p<0.05, \cdots p<0.001$

\begin{tabular}{|c|c|c|}
\hline \multirow[t]{2}{*}{ Species } & \multicolumn{2}{|c|}{ Location } \\
\hline & Platform & Soft bottom \\
\hline \multicolumn{3}{|c|}{ Cancer antennarius } \\
\hline$x_{\text {in }}$ & $102 \pm 15(110)$ & $111 \pm 14(16)$ \\
\hline$x_{i}$ & $103 \pm 14(216)$ & $104 \pm 8(7)$ \\
\hline$n_{m} /\left(n_{m}+n_{f}\right)$ & $0.34^{\cdots}$ & 0.70 \\
\hline \multicolumn{3}{|c|}{ Cancer anthonyi } \\
\hline$x_{\mathrm{m}}$ & $143 \pm 20(33)$ & $136 \pm 18(63)$ \\
\hline$x_{1}$ & $115 \pm 15(220)$ & $121 \pm 12(20)$ \\
\hline \multicolumn{2}{|c|}{ Cancer productus } & $0.76^{\circ}$ \\
\hline$x_{\mathrm{m}}$ & $161 \pm 26(5)$ & $1.75 \pm 18(8)$ \\
\hline $\begin{array}{l}x_{m} \\
x_{i}\end{array}$ & $151 \pm 18(45)$ & $150 \pm 21(11)$ \\
\hline$n_{m} /\left(n_{m}+n_{f}\right)$ & $0.10 \cdots$ & 0.42 \\
\hline \multicolumn{3}{|c|}{ Loxorhynchus grandis } \\
\hline$x_{\mathrm{m}}$ & $176 \pm 16(16)$ & $169 \pm 16(17)$ \\
\hline$x_{1}$ & $150(2)$ & $172 \pm 22(3)$ \\
\hline $\mathrm{n}_{\mathrm{m}} /\left(\mathrm{n}_{\mathrm{m}}+\mathrm{n}_{\mathrm{i}}\right)$ & 0.89 & 0.85 \\
\hline
\end{tabular}

from the platform and up to $1.5 \mathrm{yr}$ after initial tagging. No tagged individuals of the other species were reported by fishermen.

\section{Population characteristics of crabs: benthos}

All Cancer spp. individuals captured in traps on the bottom exceeded the minimum size of maturity $(C$. antennarius: $73 \mathrm{~mm} \mathrm{CW}$, Carroll 1982; C. anthonyi: 89 mm CW, Anderson \& Ford 1976; C. productus: $70 \mathrm{~mm}$ CW, Orensanz \& Gallucci 1988) and can be considered adults. The mean size of $C$. antennarius and $C$. productus captured in traps did not differ with sex or between platform and soft bottom locations (Table 2). The mean size of male $C$. anthonyi was significantly larger than that of female individuals at both platform $(p<0.001, t=10.10, \mathrm{df}=254$, Student's $t$-test $)$ and soft bottom locations $(p<0.01, t=2.78$, df $=63)$. Female $C$. anthonyi were larger at soft bottom stations than beneath the platform ( $\mathrm{p}=0.05, t=1.97$, $\mathrm{df}=240$ ).

At the platform, the proportion of male crabs (number of male crabs/total number of trapped crabs) of Cancer antennarius (0.34), C. anthonyi (0.13) and of C. productus $(0.10)$ differed significantly from 0.50 (Table 2). In contrast, at the soft bottom stations, the proportion of male crabs was not significantly different from 0.50 for $C$. antennarius and $C$. productus and 
biased towards male crabs for $C$. anthonyi (0.76: Table 2). Although not significantly different from 0.5, a trend of more male than female Loxorhynchus grandis were trapped at both platform (0.89) and soft bottom $(0.85)$ locations.

Very few Cancer antennarius ( $\geq 80 \mathrm{~mm} C L$ ) were ovigerous. Overall, only $1.8 \%(\mathrm{n}=169)$ and $8.3 \%(\mathrm{n}=$ 12) of female $C$. antennarius were ovigerous beneath the platform and on the structure, respectively. Data for $C$. anthonyi were grouped by quarter (winter = December-February, spring = March-May, summer = June-August, fall = September-November) to increase statistical power for analysis. The percent of female $C$. anthonyi that were ovigerous ranged from $0 \%$ in summer and fall to 28 and $37 \%$, respectively in winter 1996, and spring 1997. Percentage of ovigerous female crabs was positively correlated ( $\mathrm{p}<0.05, \mathrm{r}=$ 0.83 , $\mathrm{df}=6$ ) with the CPUE of females beneath the platform, if the outlying mean value of $15.3 \mathrm{crabs} \mathrm{trap}^{-1}$ in November 1995 was excluded from the analysis.

\section{The platform structure as habitat}

\section{Recruitment of crabs}

Of the 4 crab species on the benthas, only Cancer antennarius recruited onto the platform structure (Fig. 5). Recruitment was clearly seasonal; crabs $\leq 10 \mathrm{~mm} \mathrm{CW}$ were most abundant during late spring and summer. In the recruitment cages, there were no differences in the densities of crabs $\leq 10 \mathrm{~mm}$ CW among depths of 12,18 , and $24 \mathrm{~m}$ ( $\mathrm{p}>0.05,1$-way ANOVA) and the data were grouped. Densities of $C$. antennarius $\leq 10 \mathrm{~mm} C W$ were generally $<0.5$ crabs $5 \mathrm{~kg}$ mussels ${ }^{-1}$, but reached $11.0 \pm$ 5.0 and $7.1 \pm 2.8 \mathrm{crabs}^{2} \mathrm{~kg}$ mussels ${ }^{-1}$ in June 1996 and May 1997, respectively. In the mussel community samples, densities of $C$. antennarius $\leq 10 \mathrm{~mm} \mathrm{CW}$ were aiso generally $<0.5$ crabs $5 \mathrm{~kg}$ mussel $\mathrm{s}^{-1}$, except in June 1996 and June 1997 when values of $3.0 \pm 2.2$ and $2.7 \pm$ 1.8 crabs $5 \mathrm{~kg}$ mussels $^{-1}$ were recorded.

Small Cancer antennarius were also found in recruitment cages deployed on the bottom. Mean number of crabs $\leq 10 \mathrm{~mm} \mathrm{CW}$ ranged from lows of 0 to $1.7 \pm 0.9$ crabs $5 \mathrm{~kg}$ mussels ${ }^{-1}$ in August 1996 through January 1997 ( $n=3$ or 4 cages), to a high of 11.5 ( $n=2$ cages) in late March 1997.

Distribution, abundance, and population structure of crabs

Of the 4 crab species, only Cancer antennarius were observed in visual surveys on the platform. C. antennarius $\leq 10 \mathrm{~mm}$ CW were hidden within the mussel

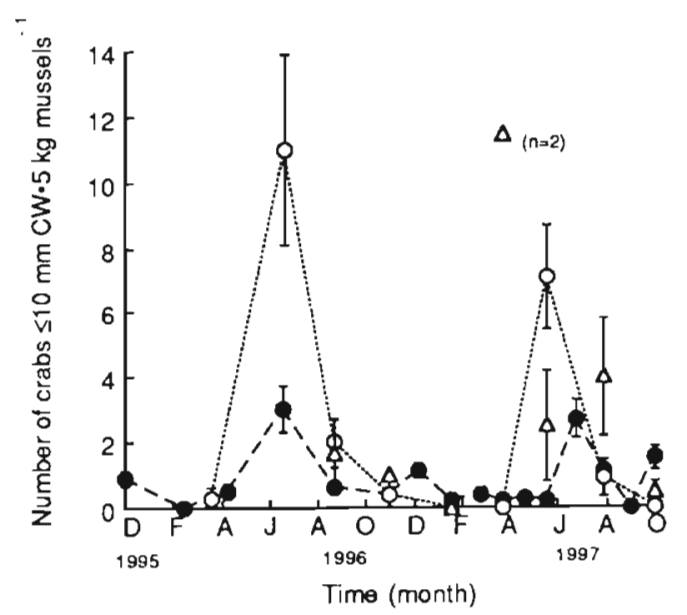

Fig. 5. Mean number of Cancer antennarius $\leq 10 \mathrm{~mm} \mathrm{CW}$ in mussel community samples from a depth of $12 \mathrm{~m}$ (-) and from recruitment cages deployed at depths of 12,18 , and $24 \mathrm{~m}$ (0) and $64 m(\Delta) . n=3$ to 6 samples or cages, $\bar{x} \pm 1 \mathrm{SE}$

community and rarely observed in those surveys. The density of crabs observed in the open and collected during visual surveys ranged from 0 to 4 crabs $\mathrm{m}^{-2}$. There was no effect of time or depth $(12,18$ and $24 \mathrm{~m})$ on crab density which, for grouped data, averaged 0.8 $\pm 0.1 \mathrm{crab} \mathrm{m}^{-2}(\bar{x} \pm 1 \mathrm{SE}, \mathrm{n}=153$ quadrats $)$.

However, if data from mussel community samples and visual surveys are combined, the density of crabs was dramatically higher at $12 \mathrm{~m}$ than at 18 or $24 \mathrm{~m}$ during late spring and early summer due to crab recruitment. For example, the density of Cancer antennarius ranged from low mean values of $1 \mathrm{crab} \mathrm{m}^{-2}$ on February 18,1996 and 9 crabs $\mathrm{m}^{-2}$ on January 18, 1997 to high values of $134 \mathrm{crabs}^{-2}$ on May 25, 1996, and 183 crabs $\mathrm{m}^{-2}$ on June 21, 1997.

Trapping data suggested that adult Cancer antennarius were less abundant on the structure than on the bottom. Mean CPUE values of adult $C$. antennarius ranged from 0 to $0.7 \pm 0.5 \mathrm{crabs} \mathrm{trap}^{-1}$ at a depth of $6 \mathrm{~m}$ compared with from $2.0 \pm 1.9$ to $6.0 \pm 1.6 \mathrm{crabs} \mathrm{trap}^{-1}$ on the bottom ( $p<0.001, t=7.76$, df $=20$, paired $t$-test: Fig. 6).

Approximately $90 \%$ of Cancer antennarius in the mussel community samples from $12 \mathrm{~m}(\mathrm{n}=137)$ were $\leq 20 \mathrm{~mm} \mathrm{CW}$ (Fig. 7). Although a distinct period of recruitment into mussel clumps was evident, there were no temporal changes in the size distribution of $C$. antennarius $>20 \mathrm{~mm} \mathrm{CW}$ sampled on the structure that might reflect individual growth within this cohort, and the data were grouped across time (Fig. 7). Most C. antennarius individuals on the structure ranged between $\sim 30$ and $70 \mathrm{~mm} \mathrm{CW}$. The proportion of male crabs collected during visual surveys $(0.56, n=615)$ was not significantly different from $0.50(\mathrm{p}>0.1$, chi-square test). 


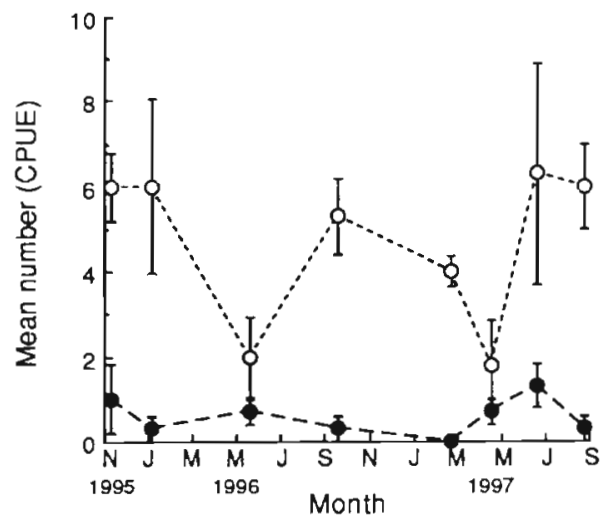

Fig. 6. Comparison of the relative abundance (as CPUE) of Cancer antennarius ( $>80 \mathrm{~mm}$ ) trapped among the conductor pipes on the structure $(6 \mathrm{~m}, \bullet)$ and on the bottom $(66 \mathrm{~m}, 0)$. $\mathrm{n}=3$ to 4 traps at each location, $\bar{x} \pm 1 \mathrm{SE}$

\section{DISCUSSION}

Two of the 4 crab species, Cancer antennarius and $C$. anthonyi, occurred in higher densities at the platform compared to the surrounding soft bottom. The platform structure, associated invertebrate community, and the altered benthos beneath the platform may contribute to this pattern by providing crabs with (1) food, (2) recruitment habitat, (3) preferred habitat of adults, and/or (4) increased shelter from predation. These 4 mechanisms, potentially responsible for the effect of the platform on the distribution and abundance of these crab species, are discussed below.

Both Cancer species could be attracted to the platform by food provided by the mussel community found from the surface to depths of $<12$ to $15 \mathrm{~m}$ and, through faunal litterfall, on the bottom. Physical disturbance is an important process that structures mussel communities in the Santa Barbara Channel (Harger 1972a,b). At Platform Holly, disturbance from storm events and platform maintenance facilitated the recruitment and growth of Mytilus galloprovincialis and this species was the principal biomass component of faunal litterfall. This species also has relatively weak byssal threads and is more easily dislodged by wave action than is M. californianus (Harger 1972a,b). Faunal litterfall has greatly modified the benthic habitat beneath the platform, creating a high relief mound qualitatively similar to that reported at other platforms offshore of California (Wolfson et al. 1979).

Faunal litterfall is continuous though temporally variable. Using mean values ranging from 121 to $2644 \mathrm{~g}$ $0.113 \mathrm{~m}^{-2}$ (Fig. 2b), we estimate that the mussel community attached to the 30 conductor pipes contributed from 47 to $1031 \mathrm{~kg}$ mussels $w^{-1}$ to the bottom. Since the area of the conductor pipes represents only a frac-
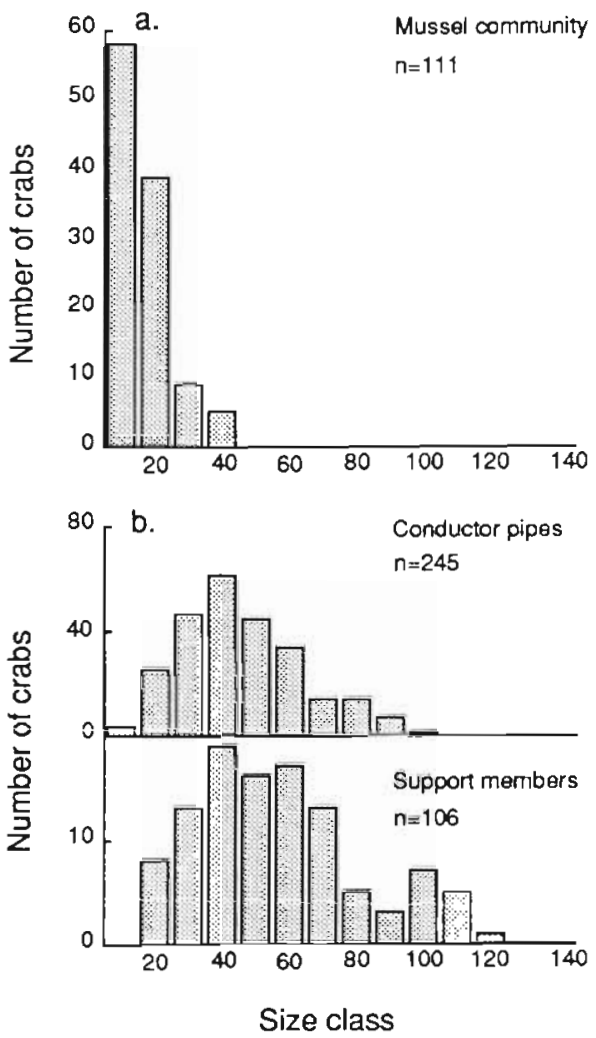

Fig. 7. Size frequency distribution of Cancer antennarius (a) within the mussel community at a depth of $12 \mathrm{~m}$ on the platform and (b) collected during visual surveys of conductor pipes and support members. Note that data collection methods differed for (a) and (b)

tion of the total submerged surface area of the platform, rates of faunal litterfall from the entire structure would be considerably higher. If food is abundant, the growth rate of crabs should be rapid. Growth rates of Cancer antennarius on the structure were considerably higher (2- to 3-fold, D. Dugan unpubl. data) than rates reported for this species in the rocky subtidal (Carroll 1982), supporting this conclusion.

The platform provides recruitment habitat only for Cancer antennarius. Recruitment contributed to elevated densities of small individuals of this species during the late winter and spring months. The timing of peak recruitment (late spring and early summer) is similar to that reported for this species elsewhere in southern California (Winn 1985). The presence of the smallest juvenile $C$. antennarius within mussel clumps is consistent with reports that this species recruits preferentially onto hard substrata (Winn 1985). This species is also reported to recruit preferentially in shallow water and late stage rock crab larvae (Cancer spp.) have been noted near the surface (Shanks 1986). There was no effect of depth $(12,18,24,66 \mathrm{~m})$ on the density 
of $C$. antennarius $\leq 10 \mathrm{~mm} \mathrm{CW}$ in recruitment cages. However, crabs could have recruited in shallow water, dropped to the bottom indirectly in association with faunal litterfall, and moved into the cages.

Recruitment cannot explain the higher densities of Cancer anthonyi at the platform compared to soft bottom. C. anthonyi megalopae may have a preference for soft substrata (Winn 1985) and we hypothesize that individuals of this species recruit onto sand or mud bottom in shallow water and move into deeper water as they grow larger. Such an ontogenic shift in habitat use exists for other Cancer species. For example, young-ofthe-year $C$. magister occur in high densities in intertidal beds of eelgrass and patches of bivalve shell fragments and move into deeper water as they grow (Armstrong \& Gunderson 1985, Stevens \& Armstrong 1985).

Habitat use is reported to differ between adult Cancer antennarius and $C$. anthonyi and a preference for hard substrata and/or structurally complex habitats may also explain, in part, the dramatically higher densities of adult $C$. antennarius at the platform compared to surrounding soft bottom. Winn (1985) reported that C. antennarius adults have a behavioral preference for hard substrata that includes rocky shores, subtidal reefs, and the interface between hard and soft bottom habitats. In contrast, $C$. anthonyi adults are reported to occur primarily on silty sand to mud substrata. This species also occurs at the interface between rocky and soft bottom habitats (Carroll \& Winn 1989) and was an important component on and around experimental artificial reefs in Santa Monica Bay (Turner et al. 1969). The recapture of $C$. anthonyi, tagged at the platform, at a distance of several kilometers by fishermen, supports the view that this species moves between the platform and surrounding soft bottom habitat.

Two lines of evidence suggest a link between elevated densities of adult Cancer anthonyi at the platform and the reproductive cycle of this species. First, the sex ratio of $C$. anthonyi beneath the platform was highly skewed towards female crabs ( $87 \%$ female), compared to the sex ratio of this species from the surrounding soft bottom ( $24 \%$ female). Second, peak abundance of this crab beneath the platform coincided with the peak in the percentage of ovigerous females (excluding the outlying data from November 1995).

Sex-specific differences in movement and habitat use also have been reported for other species of Cancer. Ovigerous C. irroratus are found in water $<30 \mathrm{~m}$ deep although the distribution of this species extends from 9 to $274 \mathrm{~m}$ (Musick \& McEachran 1972). C. magister is present in estuaries and along the open coast, but ovigerous females are found primarily along open coasts (Armstrong \& Gunderson 1985). Ovigerous C. magister are also reported to burrow deeply into sedi- ments possibly as protection against predation (O'Clair $\&$ Freese 1985). Similarily, seasonal changes in the preferred habitat of female $C$. anthonyi may enhance the survival of these individuals especially when ovigerous. The greater abundance of $C$. anthonyi beneath the platform during the winter and early spring compared with summer and fall months suggests that female crabs move seasonally between the platform and surrounding areas.

Spatial refuges from predation could be provided by the attached invertebrate community and mussel mound. Nevertheless, small Cancer antennarius (<35 mm CW) are susceptible to predation by fishes (e.g. Scorpaenichthys marmoratus), conspecifics, and other invertebrates (e.g. Octopus spp.) and we hypothesize that predation on juvenile crabs strongly influences the density and size distribution of crabs on the structure. This view is supported by 3 lines of evidence. First, our observations of an abrupt decline in crab density at sizes of $>20 \mathrm{~mm} \mathrm{CW}$. Second, recruitment cohorts failed to affect the size distribution of crabs on the structure over time through individual growth; a pattern that reflects the decline in density of newly recruited crabs. Finally, densities of crabs $\leq 10 \mathrm{~mm}$ CW were dramatically higher in recruitment cages, protected from large predators, than in uncaged mussels. In contrast, large crabs (>100 mm) are less vulnerable to predation by fish and invertebrates (Carroll \& Winn 1989) and from humans since commercial and sport fishing activity is prohibited in the vicinity of the structure.

The distribution and abundance of 2 crab species, Cancer productus and Loxorhynchus grandis, were not influenced by the platform. Individuals of these species were caught much less frequently than were C. antennarius and $C$. anthonyi . Not much is known about the distribution and abundance of these crabs. In general, $C$. productus is more abundant in northern California while $C$. antennarius and $C$. anthonyi are more abundant in southern and central California (Carroll \& Winn 1989, Parker 1992). C. productus may prefer hard substrata (Parker 1992), but this species did not recruit or aggregate at the platform. Overall, $90 \%$ of the C. productus individuals trapped beneath the platform were females, compared with $58 \%$ of the crabs on soft bottom, suggesting that the behavioral patterns of female crabs of this species are similar to those of $C$. anthonyi.

Loxorhynchus grandis individuals were present at the platform and soft bottom stations only during the late fall and early winter. Most individuals (85 to $89 \%$ ) were male. This species undergoes seasonal movements and male $L$. grandis are reported to move offshore (to depths of 50 to $60 \mathrm{~m}$ ) in fall and winter and onshore in early spring (Culver \& Kuris 1992). Female 
crabs may also undertake offshore movements, but to shallower depths. Both sexes migrate onshore in early spring and piles of adult female crabs surrounded by male crabs are observed at depths of 7 to $10 \mathrm{~m}$ in spring and summer. In general, larger crab species are highly mobile, capable of moving distances of several kilometers during seasonal migrations (e.g. review by Rebach 1983, Rodin 1989, Stone \& O'Clair 1989). In addition, seasonal differences in the distribution of male and female crabs are common. For example, female Paralithodes camtschatica are less mobile and have a narrower depth distribution than male crabs, occurring in water $<50 \mathrm{~m}$ deep during the summer and moving to deeper sites in the winter (Rodin 1989).

In conclusion, we hypothesized that the distribution and abundance of commercially important crab species around oil platforms may fit into 1 of 4 scenarios (Fig. 1). However, none of the crab species clearly fit the recruitment/emigration scenario. Although Cancer antennarius recruits to the platform, emigration of this species from the platform appears limited. There was no evidence of large-scale movement of this crab from the platform into the surrounding soft bottom habitat and a behavioral preference for hard substrate may preclude such movement. This Cancer species most closely fits the recruitment/resident scenario. In contrast, $C$. anthonyi most closely fits the attraction scenario with movement between the platform and surrounding habitat. The presence of primarily female $C$. anthonyi around the platform during the winter and spring months may involve seasonal changes in habitat use related to reproduction, behavior that has not been invoked previously to explain the attraction of mobile species to artificial structures. Finally, the distribution and abundance of C. productus and Loxorhynchus grandis most closely fit the visitor scenario. C. productus is present in low densities throughout the year while $L$. grandis is present seasonally. Our results, in the context of these scenarios, reflect interspecific differences in patterns of abundance, recruitment, and behavior, and illustrate the need to consider the responses of individual species to artificial structures such as oil platforms.

Acknowledgements. We thank S. Diehl and A. Kuris, and the anonymous reviewers for comments on the manuscript. Thanks also to numerous divers and laboratory assistants, including but not limited to C. Culver, R. Fink, J. Flattery, M. Meeker, M. Newnham, N. Quinn, and K Schmitt. G. Olivera (Mobil), J. MacDonald (Mobil, Venoco), and T. Martinez, (Venoco) and the crew of the 'Smith Tide' facilitated access to Platform Holly. M. Love supplied the videotape taken by the Delta submersible of the bottom beneath the platform. P. Freeman, C. Graham. T Luna, and C. Smith, and the Santa Barbara Fishermen's Association reported the capture of tagged crabs. This research was supported by grants from the Minerals Management Service, U.S. Department of Interior, under MMS Agreement No. 14-35-0001-30758 and the Coastal Marine Institute, University of California, Santa Barbara, to H.M.P. and J.E.D. The views and conclusions contained in this document are those of the authors and should not be interpreted as necessarily representing the official policies, either expressed or implied, of the U.S. Government.

\section{LITERATURE CITED}

Anderson WF, Ford RF (1976) Early development, growth and survival of the yellow crab Cancer anthonyi Rathbun (Decapoda, Brachyura) in the laboratory. Aquaculture 7: $267-279$

Armstrong DA, Gunderson DR (1985) The role of estuaries in Dungeness crab early life history: a case study in Grays Harbor, Washington. In: Proceedings of the symposium on Dungeness crab biology and management. Alaska Sea Grant Report No 85-3, Anchorage, p 145-170

Bascom WA, Mearns J, Moore MD (1976) A biological survey of oil platforms in the Santa Barbara Channel. J Petroleum Tech 28:1280-1284

Bohnsack JA (1989) Are high densities of fishes at artificial reefs the result of habitat limitation or behavioral preference? Bull Mar Sci 44:631-645

Bohnsack JA, Sutherland DL (1985) Artificial reef research: a review with recommendations for future priorities. Bull Mar Sci 37:11-39

Bohnsack JA, Ecklund AM, Szmant AM (1997) Artificial reef research: is there more than the attraction-production issue? Fisheries 22:14-16

Carr $\mathrm{MH}$, Hixon MA (1997) Artificial reefs: the importance of comparisons with natural reefs. Fisheries 22:28-33

Carroll JC (1982) Seasonal abundance, size composition and growth of rock crab, Cancer antennarius Stimpson, off central California. J Crustac Biol 2:549-561

Carroll JC, Winn RN (1989) Species profiles: Life histories and environmental requirements of coastal fishes and invertebrates (Pacific Southwest) Brown Rock Crab, Red Rock Crab, and Yellow Crab. In: U.S. Army Corps of Engineers Report No TR EL-82-4, U.S. Fish and Wildlife Service Biological Report 82 (11.117), Vicksburg, MS

Culver CS, Kuris AM (1992) Sheep crab. In: Leet WS, Dewees CM, Haugen CW (eds) California's living marine resources and their utilization. California Sea Grant, Sea Grant Extension Publication UCSGEP-92-12, Davis, CA, p 20-22

Davis NG, VanBlaricom R, Dayton PK (1982) Man-made structures: effects on adjacent benthic communities. Mar Biol 70:295-303

Harger JRE (1972a) Competitive coexistence: maintenance of interacting associations of the sea mussels Mytilus edulis and Mytilus californianus. Veliger 14:387-410

Harger JRE (1972b) Competitive coexistence among intertidal invertebrates. Am Sci 60:600-607

Herrnkind WF, Butler MJ IV, Hunt JH (1997) Can artificial habitats that mimic natural structures enhance recruitment of Caribbean spiny lobster? Fisheries 22:24-27

Lindberg WJ (1997) Can science resolve the attraction-production issue? Fisheries 22:10-13

Love $M$, Hyland J, Ebeling A, Herrlinger $I$, Brooks A, Imamura $E$ (1994) A pilot study of the distribution and abundances of rockfishes in relation to natural environmental factors and an offshore oil and gas production platform off the coast of southern California. Bull Mar Sci 55:1062-1085

MBC Applied Environmental Sciences (1987) Ecology of oil/gas platforms offshore California. U.S. Dept Interior, OCS Study/MMS 86-0094, Los Angeles 
MMS/California State Lands Commission (1994) Abandonment and removal of offshore oil and gas facilities: education and information transfer. Workshop Proceedings. University of California, Santa Barbara

Musick TA, McEachran JD (1972) Autumn and winter occurrence of decapod crustaceans in Chesapeake Bight, U.S.A. Crustaceana 22:190-200

O'Clair CE, Freese I (1985) Responses of Dungeness crabs, Cancer magister, exposed to bark debris from benthic deposits at log transfer facilities: survival, feeding, and reproduction. In: Proceedings of the Symposium on Dungeness Crab Biology and Management, Alaska Sea Grant Report No 85-3, Anchorage, p 227-229

Orensanz JM, Gallucci VF (1988) Comparative study of postlarval life-history schedules in four sympatric species of Cancer (Decapoda: Brachyura: Cancridae). J Crustac Biol 8:187-220

Page HM (1986) Differences in population structure and growth rate of the stalked barnacle Pollicipes polymerus between a rocky headland and an offshore oil platform. Mar Ecol Prog Ser 29:157-164

Page HM, Hubbard DM (1987) Temporal and spatial patterns of growth in mussels Mytilus edulis on an offshore platform: relationships to water temperature and food availability. J Exp Mar Biol Ecol 111:159-179

Parker D (1992) Rock crabs. In: Leet WS, Dewees CM, Haugen CW (eds) California's living marine resources and their utilization. California Sea Grant, Sea Grant Extension Publication, University of California, San Diego, UCSGEP-92-12, p 18-20

Picken GB, McIntyre AD (1989) Rigs to reefs in the North Sea Bull Mar Sci 44:782-788

Pickering H. Whitmarsh D (1997) Artificial reefs and fisheries exploitation: a review of the 'attraction versus production' debate, the influence of design and its significance for policy. Fish Res 31:39-59

Rebach S (1983) Orientation and migration in Crustacea. In Rebach S, Dunham DW (eds) Studies in adaptation. The behavior of higher Crustacea. John Wiley \& Sons, New York, p 217-264

Reggio VC (1987) Rigs-to-reefs. Fisheries 12:2-7

Reggio VC (1989) Petroleum structures as artificial reefs: a

Editorial responsibility: Otto Kinne (Editor),

Oldendorf/Luhe, Germany compendium. In: Fourth International Conference on Artificial Habitats for Fisheries. Rigs-to-Reefs Special Session, Miami, FL, OCS Study/MMS 89-0021

Rodin VE (1989) Population biology of the King crab Paralithodes camtschatica Tilesius in the North Pacific Ocean. In: Proceedings of the International Symposium on King and Tanner crabs. Alaska Sea Grant College Progress Report No 90-04, Anchorage, p 133-144

Shanks AL (1986) Vertical migration and cross-shelf dispersal of larval Cancer spp. and Randallia ornata (Crustacea: Brachyura) off the coast of southern California. Mar Biol 92:189-199

Stevens BG, Armstrong DA (1985) Ecology, growth, and population dynamics of juvenile Dungeness crab, Cancer magister Dana, in Grays Harbor, Washington, 1980-1981. In: Proceedings of the symposium on Dungeness crab biology and management. Alaska Sea Grant Report No 85-3, Anchorage, p 119-134

Stimpson RA (1977) The biology of two offshore oil platforms. Institute Marine Research, University of California, San Diego, IMR Reference 76-13

Stone RP, O'Clair CE (1989) Seasonal migration of primiparous and multiparous female red king crabs (Paralithodes camtschatica). In: Proceedings of the International Symposium on King and Tanner Crabs. Alaska Sea Grant College Progress Report No 90-04, Anchorage, p 189- 191

Turner CH, Ebert EE, Given RR (1969) Man-made reef ecology. State of California, Department of Fish and Game, Fish Bulletin 146, Sacramento, CA

Wilkinson L, Hill M, Vang E (1992) SYSTAT: statistics, version 5.2 edition. SYSTAT, Inc, Evanston, IL

Winn RN (1985) Comparative ecology of three Cancrid crab species (Cancer anthonyi, C. antennarius and C. productus) in marine subtidal habitats in southern California. PhD dissertation, University of Southern California, Los Angeles

Wolfson A, VanBlaricom G, Davis N, Lewbel GS (1979) The marine life of an offshore oil platform. Mar Ecol Prog Ser 1: $81-89$

Zar J (1984) Biostatistical analysis. Prentice-Hall, Englewood Cliffs, NJ

Submitted: May 18, 1998; Accepted: March 2, 1999

Proofs received from author(s): July 29, 1999 